\title{
Variable response of coastal sharks to severe tropical storms: environmental cues and changes in space use
}

\author{
Vinay Udyawer ${ }^{1, *}$, Andrew Chin ${ }^{1}$, Danielle M. Knip ${ }^{2}$, Colin A. Simpfendorfer ${ }^{1}$, \\ Michelle R. Heupel ${ }^{1,3}$ \\ ${ }^{1}$ Centre for Sustainable Tropical Fisheries and Aquaculture \& School of Earth and Environmental Sciences, \\ James Cook University, Townsville, Queensland 4811, Australia \\ ${ }^{2}$ Sea Around Us Project, Fisheries Centre, 2202 Main Mall, The University of British Columbia, Vancouver, British Columbia \\ V6T 1Z4, Canada \\ ${ }^{3}$ Australian Institute of Marine Science, Townsville, Queensland 4810, Australia
}

\begin{abstract}
Acute disturbance events like tropical storms can have significant effects on coastal habitats and animals that utilise them. We examined environmental parameters as cues for flight behaviour based on movement data from 5 species of elasmobranch (Carcharhinus limbatus, C. tilstoni, C. melanopterus, C. sorrah and C. amboinensis) during 3 tropical storm events in 2 coastal bays on 2 continents (Cleveland Bay, Australia, and Terra Ceia Bay, USA). Individuals were monitored using passive acoustic telemetry before, during and after the storms. Short-term effects on movement and distribution were investigated in relation to environmental parameters (barometric pressure, wind speed and wave height) along with longer-term changes in size and location of activity spaces of individuals due to extreme weather events. Short-term flight behaviour was observed in 4 species, with $C$. melanopterus the only species showing no reaction to storm events. Change of activity space size and location varied within the 2 study sites, with significant changes in activity spaces only occurring in Terra Ceia Bay. Examination of environmental parameters as cues for flight behaviour showed that species had varying tolerances to environmental conditions during storm events. Flight behaviour was observed in juvenile individuals that had not experienced such conditions before, which may suggest that this behavioural response is innate.
\end{abstract}

KEY WORDS: Elasmobranch $\cdot$ Behaviour $\cdot$ Disturbance event $\cdot$ Extreme weather $\cdot$ Acoustic telemetry $\cdot$ Flight response

Resale or republication not permitted without written consent of the publisher

\section{INTRODUCTION}

Periods of acute disturbance caused by weather events are important drivers of ecosystem structure and function in both shallow-water environments (Thistle 1981, Davis et al. 2004) and deeper-water communities (Posey et al. 1996). Animal movement in response to such natural disturbance events has been observed previously in invertebrates (Jury et al. 1995), teleosts (Patterson et al. 2001), marine reptiles (Dodd \& Byles 2003, Liu et al. 2010) and elasmobranchs (Heupel et al. 2003, Simpfendorfer \& Wiley
2006). Extreme weather events within coastal habitats have implications for the services these habitats provide to animals that use them (Davis et al. 2004) and directly for the populations of animals that use them (Matich \& Heithaus 2012). Understanding the movement patterns of individuals during the course of an extreme weather event can provide important information on behavioural responses to extreme conditions, and potentially help in predicting the effects of climate change in locations where severe tropical storms may become more prevalent (Chin et al. 2010, Simpfendorfer et al. 2011). 
Behavioural responses of elasmobranchs in coastal waters to large storm events have been observed previously by Heupel et al. (2003). That study found that blacktip sharks Carcharhinus limbatus left Terra Ceia Bay (Florida, USA) prior to the arrival of Tropical Storm Gabrielle, likely due to a drop in barometric pressure and deteriorating conditions within the bay (e.g. increased wave height). In the present study, we used the same data set to evaluate the thresholds at which C. limbatus in Terra Ceia Bay seek out deep-water refuges to avoid adverse conditions and to quantify how habitat use differed before and after the storm, and we compared these results to the responses of other coastal sharks in another tropical ecosystem that is affected by storms.

Sharks and other fish species have highly sensitive mechanoreceptors within the inner ear that can detect subtle changes in hydrostatic pressure very accurately (Fraser \& Shelmerdine 2002). Flight behaviour based on changes in environmental conditions may be a mechanism of avoiding shallow areas during extreme weather events, and there is also some indication that flight behaviour may be an innate response (Heupel et al. 2003). In addition, sharks display a flight response to extreme changes in other environmental parameters, including drops in water temperature (Matich \& Heithaus 2012) and salinity (Ubeda et al. 2009, Knip et al. 2011a,b). Acute changes in environmental conditions can therefore result in significant changes in behaviour that may ultimately have effects on populations and ecosystems, depending on the magnitude and duration of the response.

Rapid change in environmental conditions during the onset of large tropical storms has significant effects on the behaviour and movement of coastal fishes including elasmobranchs (Patterson et al. 2001, Heupel et al. 2003). The aims of this study were to (a) determine the short-term responses of coastal sharks to severe tropical storms, (b) determine whether such storms cause medium to long-term changes in the distribution of sharks within coastal habitats and (c) use presence data of sharks within coastal habitats to estimate threshold values of environmental parameters that trigger flight responses.

\section{MATERIALS AND METHODS}

\section{Study areas}

The movement and behaviour of shark populations were examined in 2 locations, Cleveland Bay in
Queensland, Australia, and Terra Ceia Bay in Florida, USA, to investigate the responses of sharks to tropical storms. Both bays are located in tropical or subtropical areas. Movements of animals were examined using passive acoustic telemetry, with arrays of acoustic receivers present within the study areas before, during and after storm events. Acoustic receivers, each with a single frequency omnidirectional hydrophone that operated at $69 \mathrm{kHz}$, were deployed to log detection data from sharks fitted with acoustic transmitters. Receivers were deployed in Cleveland and Terra Ceia Bays employing methodology previously described (Heupel \& Hueter 2001, Knip et al. 2011a,b).

Cleveland Bay is located on the northeast coast of Queensland $\left(19.20^{\circ} \mathrm{S}, 146.92^{\circ} \mathrm{E}\right.$; Fig. 1a), is mostly less than $10 \mathrm{~m}$ deep and has a maximum tidal range of approximately $4 \mathrm{~m}$. The bay covers an area of approximately $225 \mathrm{~km}^{2}$ and consists mainly of soft sediment substrates. There are extensive seagrass beds and small patches of coral reef within the bay, and the southern shore is lined with mangrove habitat. Several sources of freshwater enter the bay from the southern end and provide the majority of freshwater input. An array of 63 VR2 and VR2W acoustic receivers (Vemco) was used. Receivers were positioned in fixed locations to cover the eastern and western sections of the bay that corresponded to Conservation Park zones within the Great Barrier Reef Marine Park. Movement and habitat use of 4 shark species (Australian blacktip Carcharhinus tilstoni, $\mathrm{n}=5$; blacktip reef $C$. melanopterus, $\mathrm{n}=16$; spottail $C$. sorrah, $\mathrm{n}=9$; and pigeye shark $C$. amboinensis, $\mathrm{n}=7$ ) were examined within Cleveland Bay between 6 January and 4 March 2011 during which 2 tropical cyclones occurred within the region. Individuals of $C$. tilstoni were tagged between November 2010 and February 2011, whereas individuals of C. melanopterus, C. sorrah and C. amboinensis were all tagged in 2009 and early 2010 as part of larger monitoring studies (Knip et al. 2011a,b, 2012).

Terra Ceia Bay, located on the Gulf of Mexico coast of Florida $\left(27.55^{\circ} \mathrm{N}, 82.58^{\circ} \mathrm{W}\right)$, is a small, shallow bay adjacent to Tampa Bay (Fig. 1b) covering an area of approximately $10 \mathrm{~km}^{2}$, with a maximum depth of about $4 \mathrm{~m}$. Comparatively, this bay is more restricted than Cleveland Bay, with 1 passage that connects the bay to the larger Tampa Bay region. The bay is lined with mangroves and has 1 source that provides limited freshwater input into the north end of the bay. An array of 25 VR2 receivers (Vemco) was used, with 18 receivers placed within the bay, 3 within the passage connecting Terra Ceia Bay to Tampa Bay and 4 outside the bay (Fig. 1b). Movements of 14 Car- 


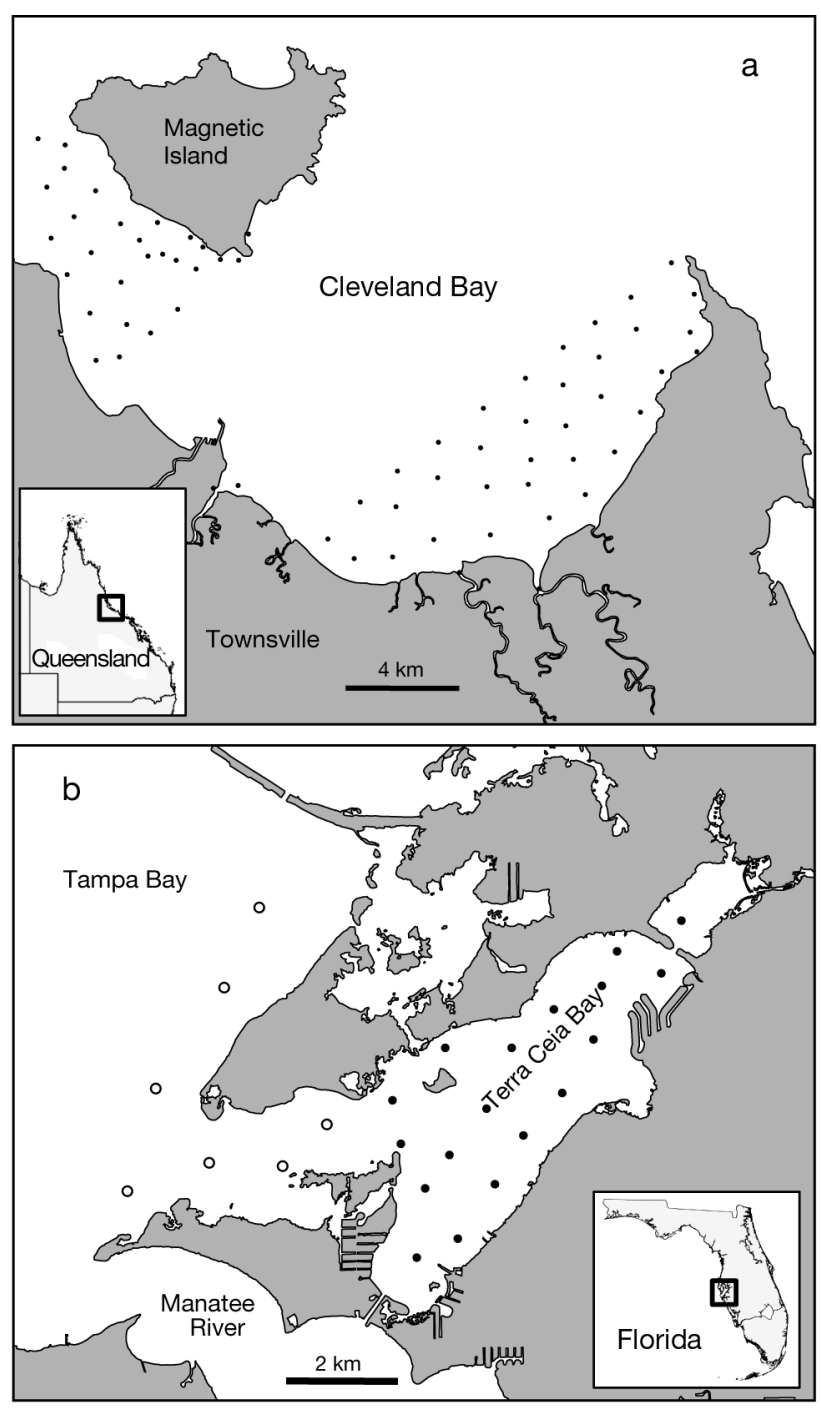

Fig. 1. Study sites at (a) Cleveland Bay, Australia, with solid points representing locations of acoustic receivers within the bay, and (b) Terra Ceia Bay, USA, with solid points representing locations of acoustic receivers within the bay, and open points representing locations of receivers within the passage and outside Terra Ceia Bay

charhinus limbatus were examined within the bay between 25 August and 26 October 2001 during which 1 tropical storm passed through the region. All individuals were tagged in early June 2001 as part of a larger monitoring study (e.g. Heupel et al. 2004, Heupel 2007).

\section{Field methods}

Sharks at both study sites were captured using baited, short multi-hook research lines or rod and reel fishing. Once captured, sharks were sexed, measured, and tagged with a rototag in the first dorsal fin or a single-barb dart tag in the dorsal musculature. Individuals in good condition and within the appropriate size range $(>50 \mathrm{~cm}$ stretch total length, STL) were surgically implanted with Vemco V16 RCODE $16 \times 65 \mathrm{~mm}$ acoustic transmitters. Surgeries were conducted as per methods described by Heupel \& Hueter (2001). All individuals were released in good condition at their location of capture. Transmitters were uniquely coded for each individual and transmitted at $69 \mathrm{kHz}$. The signal was repeated in a random interval between 45 to $75 \mathrm{~s}$ to reduce the likelihood of signals from 2 or more tags overlapping and thus not being detected. Transmitters used at both study sites had a battery life of approximately $18 \mathrm{mo}$.

\section{Storm events}

Three storm events with varying intensities were encountered in close proximity to the study sites. Environmental data for each event were compared to detection data from monitored species for periods before and after individual storm events.

In Cleveland Bay, 2 storm events occurred within close proximity to the study site in January and February 2011. Tropical Cyclone (TC) Anthony, classified as a category 2 cyclone (Australian Tropical Cyclone Intensity Scale) at its peak with sustained wind speeds of ca. $100 \mathrm{~km} \mathrm{~h}^{-1}$, made landfall approximately $170 \mathrm{~km}$ south of the study site on 30 January 2011. Maximum sustained wind speeds within Cleveland Bay during TC Anthony were measured at $42.4 \mathrm{~km} \mathrm{~h}^{-1}$ with the barometric pressure dropping as low as $1008.4 \mathrm{hPa}$. This storm event was closely followed by a much larger storm, TC Yasi, that was classified as a category 5 cyclone at its peak with estimated sustained wind speeds of ca. $205 \mathrm{~km} \mathrm{~h}^{-1}$ and made landfall approximately $160 \mathrm{~km}$ north of the study site on 3 February 2011. Maximum sustained wind speeds within Cleveland Bay were measured at $106.3 \mathrm{~km} \mathrm{~h}^{-1}$ with the barometric pressure dropping as low as $990.8 \mathrm{hPa}$.

In Terra Ceia Bay, Tropical Strom (TS) Gabrielle, which developed in the Gulf of Mexico, was classified as a category 1 hurricane (Saffir-Simpson Hurricane Scale), with sustained wind speeds recorded at $>100 \mathrm{~km} \mathrm{~h}^{-1}$ in some locations. It made landfall on the central coast of Florida $50 \mathrm{~km}$ south of the study site on 14 September 2001 and was previously described by Heupel et al. (2003). Maximum sustained wind 
speeds within Terra Ceia Bay during the storm were measured at $81.6 \mathrm{~km} \mathrm{~h}^{-1}$ with the barometric pressure dropping as low as $996.1 \mathrm{hPa}$.

\section{Data analysis}

Hourly presence of individuals within acoustic arrays was investigated by examining detections of individuals prior to, during and after storm events. All raw data were refined to only include 2 or more detections $\mathrm{h}^{-1}$ to remove false positives prior to further analysis. Hourly presence of 4 species (Carcharhinus tilstoni, C. melanopterus, C. sorrah and C. amboinensis) in Cleveland Bay was investigated in conjunction with environmental data (barometric pressure and wind speed) for the period $2 \mathrm{~d}$ prior to TC Anthony and $3 \mathrm{~d}$ after the landfall of TC Yasi. Hourly presence of $C$. limbatus was investigated for a period of $4 \mathrm{~d}$ before and $26 \mathrm{~d}$ after the landfall of TS Gabrielle. Time intervals for each study site were chosen to include the periods where the majority of monitored individuals ( $>70 \%$ ) were detected within the study sites prior to and after the storm events. Detection data were also used to determine the spatial pattern of exit and entry before and after storm events in Cleveland Bay. Exit and entry detections were used because in extreme conditions, acoustic receivers may stop detecting signals from tags because of the increased wave action and associated sedimentation, which could be mistaken for animals departing the array. The acoustic array had 3 exit and entry points: a large passage on the eastern side of the array, and 2 passages on either side of Magnetic Island (Fig. 1a). The departure and return paths of each shark were compared across individuals and species within Cleveland Bay to determine where the animals may have moved to during the storm event. A similar analysis was not conducted for Terra Ceia Bay, as that site has only 1 point of exit/entry.

Threshold values of environmental parameters were determined by examining the probability of detecting animals within the array under changing conditions associated with tropical storms. Hourly presence of individuals was converted into binary response variables. The analysis was applied to individuals that were heard consistently (at least 2 detections $\mathrm{d}^{-1}$ ) for $3 \mathrm{~d}$ prior to storm events. Binomial general linear models with a logit link function were used to estimate probability of detection within the acoustic arrays as a function of barometric pressure, wind speed and wave height. The threshold value was estimated by interpolating the environmental variable at which $50 \%$ of individuals were no longer detected within the array. The threshold value at the $50 \%$ probability was chosen as it represents the median conditions at which individuals were observed to leave the site prior to the storm event and allowed for comparison of responses between species within each site. Hourly presence data for each species were examined for the $3 \mathrm{~d}$ prior to tropical storms.

A kernel utilisation distribution (KUD) analysis (Calenge 2011) was used to estimate whether there were differences in the size and location of individuals' activity spaces (50\% KUD: core; and 95\% KUD: extent) before and after storm events at both sites. Raw detection data were processed through a mean position algorithm that computed an individual's centre of activity (COA) at 30 min intervals (Simpfendorfer et al. 2002). KUD analyses based on COA estimates were conducted using the adehabitat software package in the $\mathrm{R}$ environment (Calenge 2006). In Cleveland Bay, data for individuals $30 \mathrm{~d}$ before and after TC Yasi were included in the KUD analysis, and in Terra Ceia Bay, data from $20 \mathrm{~d}$ before TS Gabrielle and $20 \mathrm{~d}$ after individuals had returned to the bay continuously (i.e. $21 \mathrm{~d}$ after the storm passed) were included in the KUD analysis. These time scales were chosen for these sites to maximise the use of available environmental data and had the majority of monitored animals detected within the sites. The size of individual activity spaces before and after the storm events was compared using an analysis of covariance (ANCOVA) with sex and total length as covariates. Change in location of activity spaces was examined by calculating the proportion of overlap between activity spaces before and after storms. A smaller proportion of overlap meant that the location of the activity space had changed by a larger degree after a storm and vice versa.

\section{RESULTS}

\section{Presence}

\section{Cleveland Bay}

Analysis included all 4 monitored species: Carcharhinus tilstoni (size range: $52-75 \mathrm{~cm}$; 4 males, 1 female), C. sorrah (102-126 cm; 4 males, 5 females), C. amboinensis (74-129 cm; 4 males, 3 females) and C. melanopterus (65-148 cm; 7 males, 9 females). There was no apparent change in presence prior to the arrival of TC Anthony; however, a clear flight 


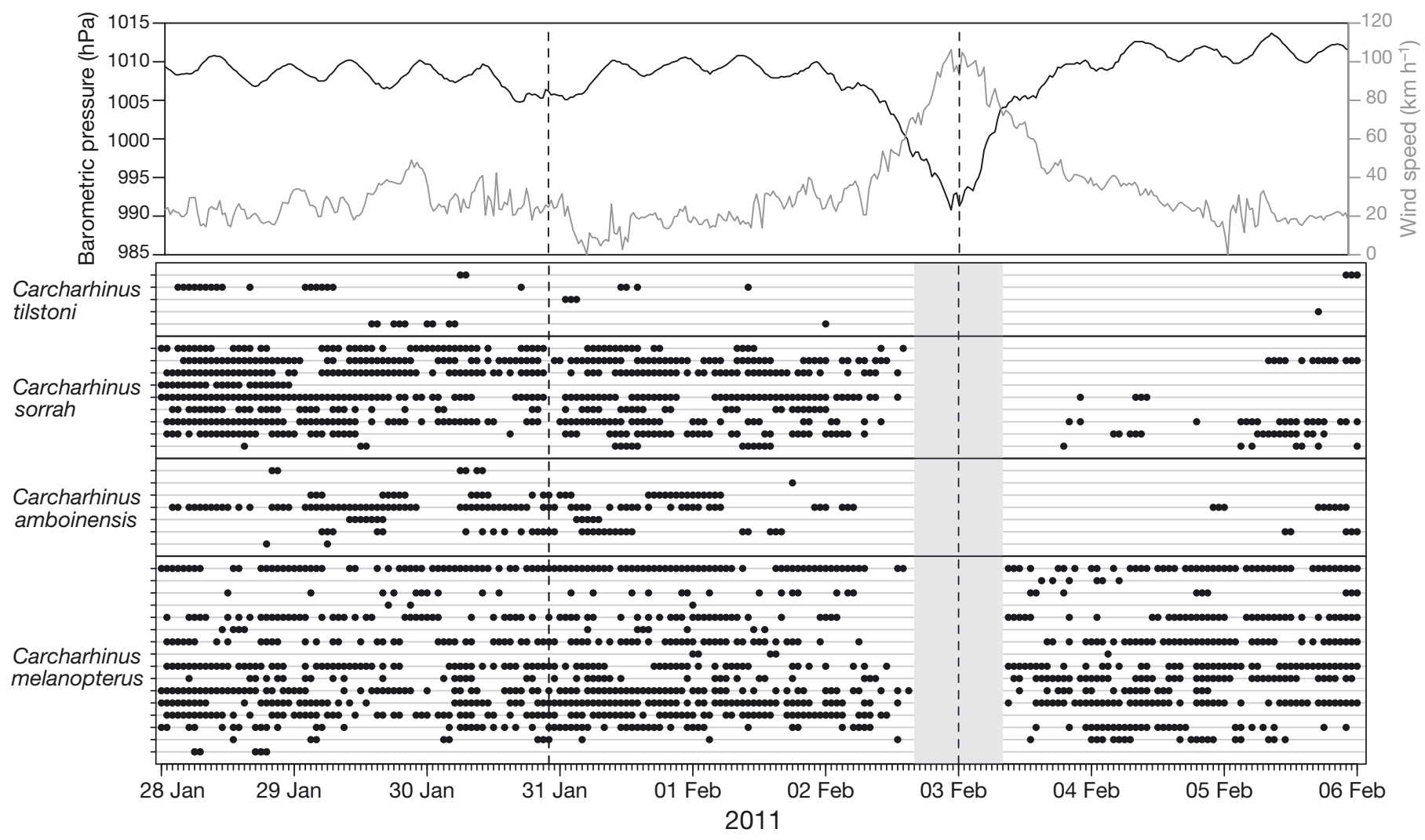

Fig. 2. Carcharhinus spp. Hourly presence of individuals within Cleveland Bay. Top panel plots environmental data (black line: barometric pressure, grey line: wind speed) with detections in the bottom panel. The first broken vertical line represents landfall of Tropical Cyclone (TC) Anthony; the second broken line represents landfall of TC Yasi. The grey shaded area represents the period where no sharks were detected

response was observed prior to the onset of TC Yasi (Fig. 2). Flight response to the storm was observed in C. tilstoni, C. amboinensis, and C. sorrah which were last detected 10 to $24 \mathrm{~h}$ prior to TC Yasi making landfall, and detected returning 18 to $65 \mathrm{~h}$ after landfall. Eleven of 16 C. melanopterus were detected within the array on the day TC Yasi made landfall, suggesting they displayed restricted movements and may not have left the study area. No individuals of any species were detected approximately $8 \mathrm{~h}$ before and after landfall of TC Yasi.

Individuals present on the eastern side of Cleveland Bay prior to TC Yasi (Carcharhinus tilstoni, C. sorrah and $C$. amboinensis) were last detected by receivers on the eastern side (Fig. 3), indicating that they exited into the central portion of the bay and did not make alongshore movements through the western side of Cleveland Bay. However, on return, 2 C. tilstoni and 2 C. amboinensis were first detected by the far western receivers, suggesting that these individuals had moved outside the bay into deeper water north of Magnetic Island (Fig. 3), and returned south via the western passage. The remaining $C$. amboinensis and all $C$. sorrah that exited via the eastern side were detected re-entering the bay by receivers located on the eastern side. Individual $C$. melanopterus were last detected before the storm and first recorded after the storm by receivers in the middle of the western side of the array (Fig. 3), further supporting the conclusion that these individuals displayed very restricted movement within the array during the storm event.

\section{Terra Ceia Bay}

Of 14 C. limbatus (size range: $54-61 \mathrm{~cm} ; 5$ males, 9 females), 13 were consistently detected before and after the storm event. No individuals were detected inside the bay 3 to $6 \mathrm{~h}$ prior to TS Gabrielle making landfall (Fig. 4). Detections were consistently recorded outside the bay for a period of approximately 6 to $7 \mathrm{~d}$ after TS Gabrielle made landfall. Approximately $21 \mathrm{~d}$ after landfall, animals were consistently 


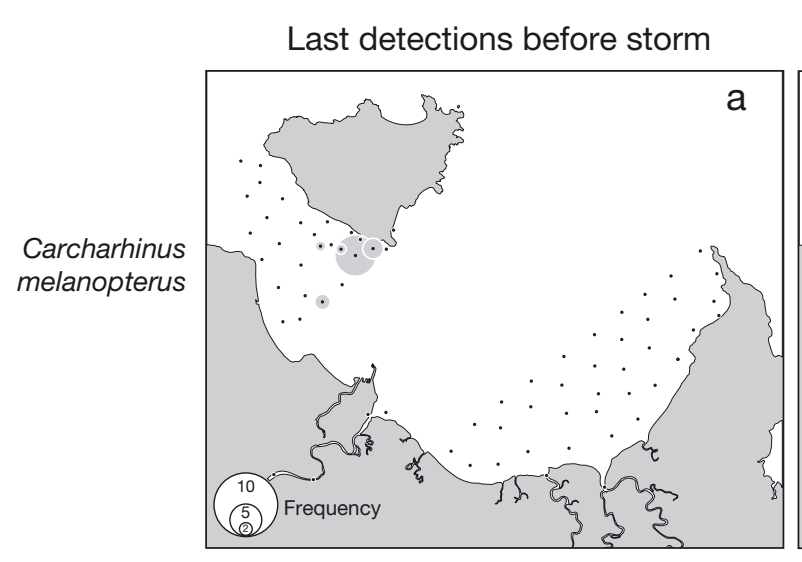

First detections after storm
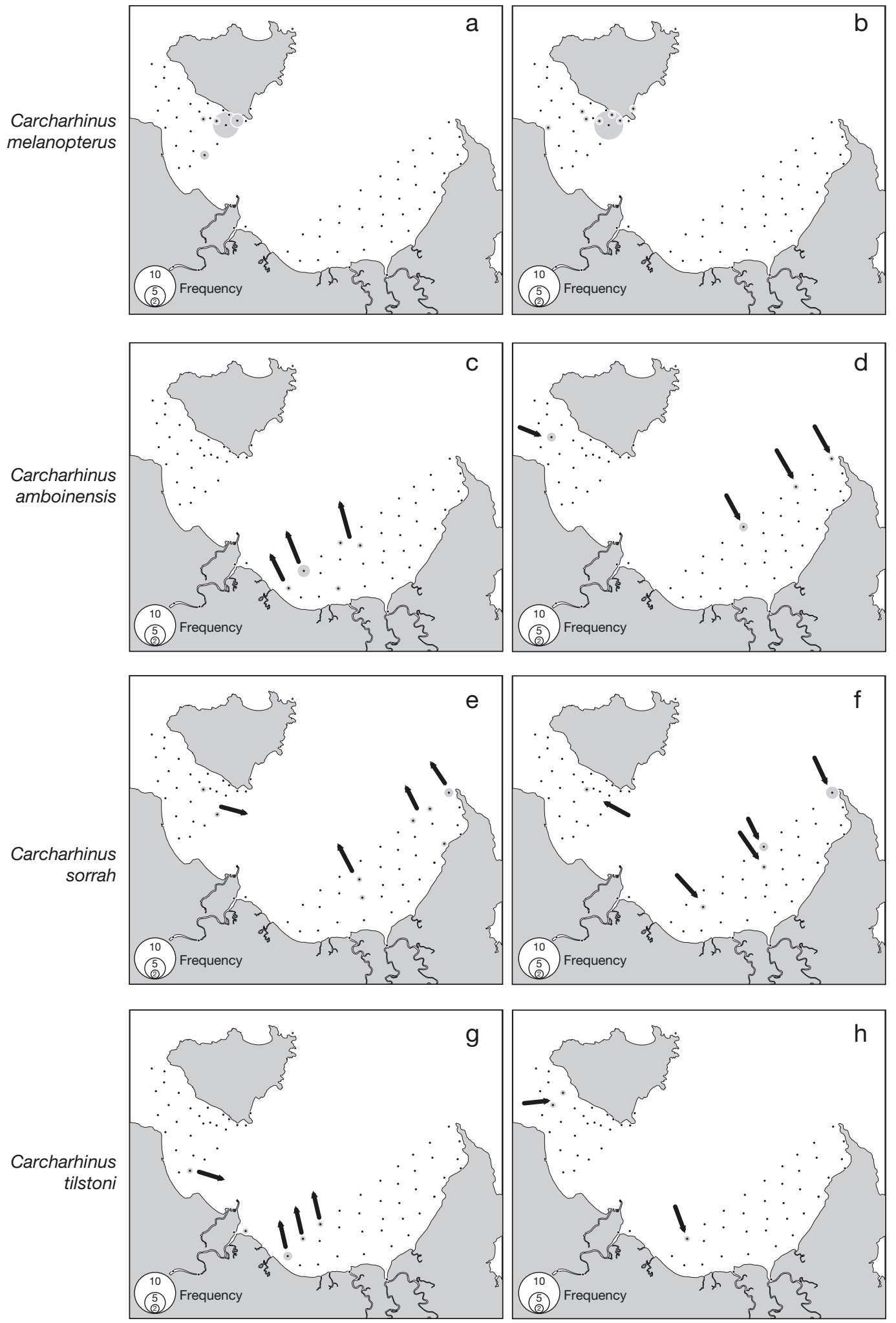

Fig. 3. Carcharhinus spp. Exit and entry detections within Cleveland Bay during Tropical Cyclone (TC) Yasi. Bubble plots represent the number of detections last heard prior to TC Yasi (left panels) and detections first heard after TC Yasi passed (right panels). (a,b) C. melanopterus, $(\mathrm{c}, \mathrm{d})$ C. amboinensis, $(\mathrm{e}, \mathrm{f})$ C. sorrah, $(\mathrm{g}, \mathrm{h})$ C. tilstoni. Key represents sizes of bubbles for 2,5 and 10 detections 


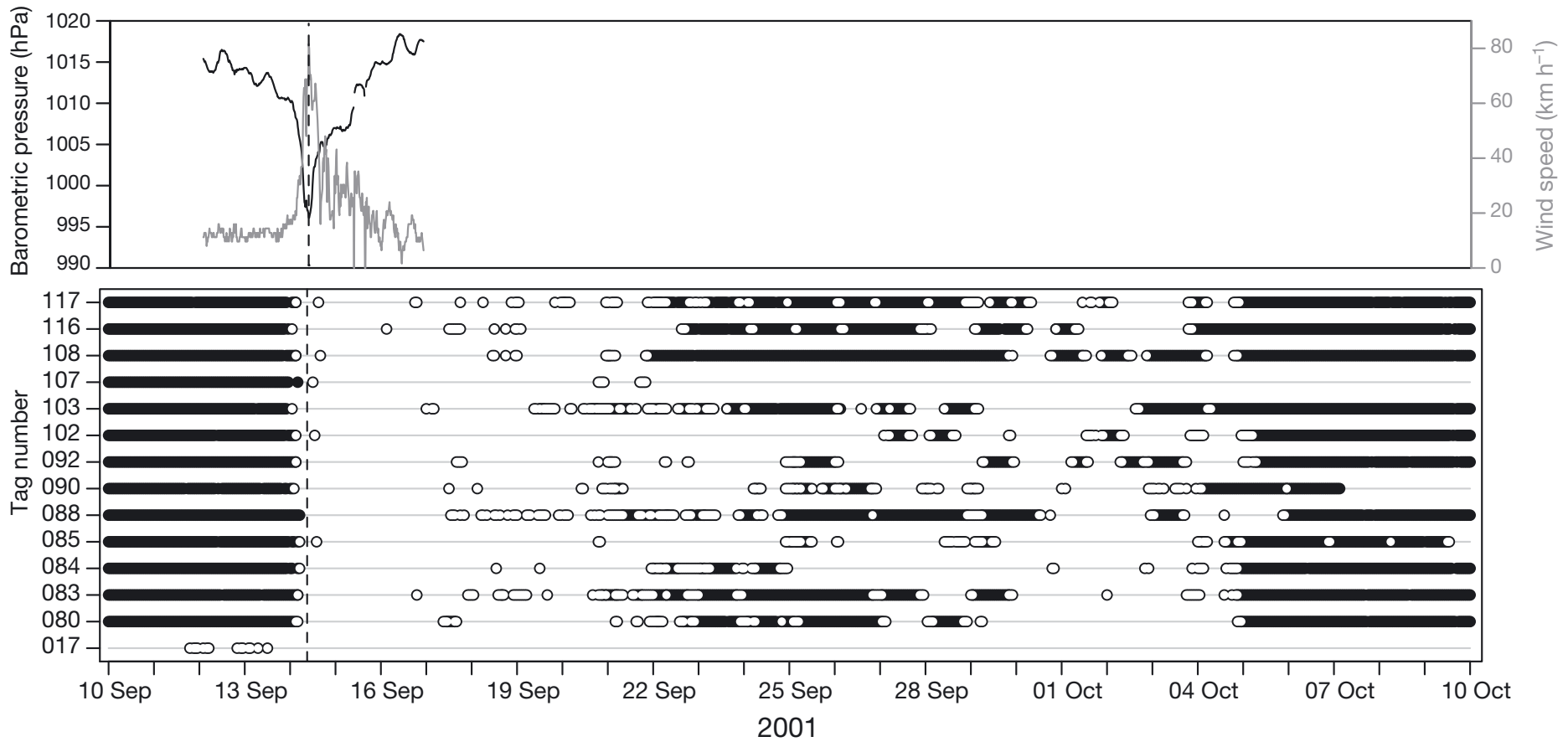

Fig. 4. Carcharhinus limbatus. Hourly presence of individuals within Terra Ceia Bay. Top panel plots environmental data (black line: barometric pressure; grey line: wind speed) during period of storm event with detections in the bottom panel. Broken vertical line represents landfall of Tropical Storm Gabrielle. Solid points represent detections within the bay and open points represent detections outside the bay

detected within the bay, and detection patterns returned to pre-storm patterns. All individuals showed similar short-term responses to the onset of TS Gabrielle, and 10 of 14 individuals returned to the bay after conditions stabilised.

\section{Environmental thresholds}

The logistic regression for individual presence within the 2 study sites in relation to barometric pressure, wind speed and wave height revealed a strong correlation in the logit function for all environmental variables (Fig. 5a,b), with similar results for barometric pressure and wind speed from both study sites. The analysis yielded reliable threshold results for Carcharhinus melanopterus, C. amboinensis, C. sorrah and $C$. limbatus (Table 1); however, the residency of $C$. tilstoni was not high enough for this analysis to determine environmental thresholds with enough certainty.

Carcharhinus melanopterus showed the highest tolerance to degrading conditions and had the lowest barometric threshold $(999.3 \mathrm{hPa})$, as well as the highest thresholds for sustained wind speed $\left(67.2 \mathrm{~km} \mathrm{~h}^{-1}\right)$ and wave height $(3.3 \mathrm{~m})$. Given that the exit-entry detection data indicated that this species remained within the bay, these threshold values probably represent receiver performance during the storm. C. sorrah showed the next highest level of tolerance to deteriorating conditions, and C. amboinensis had the lowest tolerance threshold to barometric pressure $(1006.4 \mathrm{hPa})$, wind speed $\left(29.5 \mathrm{~km} \mathrm{~h}^{-1}\right)$ and wave height $(1.0 \mathrm{~m})$. A strong correlation in the logit function was found between the presence of $C$. limbatus individuals and barometric pressure and wind speed (Fig. 5b). The barometric threshold value estimated for this storm event (1007.4 hPa) was higher, and the wind speed threshold value $\left(24.6 \mathrm{~km} \mathrm{~h}^{-1}\right)$ was lower, than those calculated in Cleveland Bay (Table 1).

\section{Activity space}

We found no significant difference in the size of activity space (core or extent) before and after TC Yasi for any species in Cleveland Bay, and neither sex nor length had significant effects on activity space (Table 2). Overlap analysis revealed a high degree of overlap between activity spaces of individuals before and after TC Yasi (Fig. 6a). A higher degree of overlap was observed for the extent of 
a
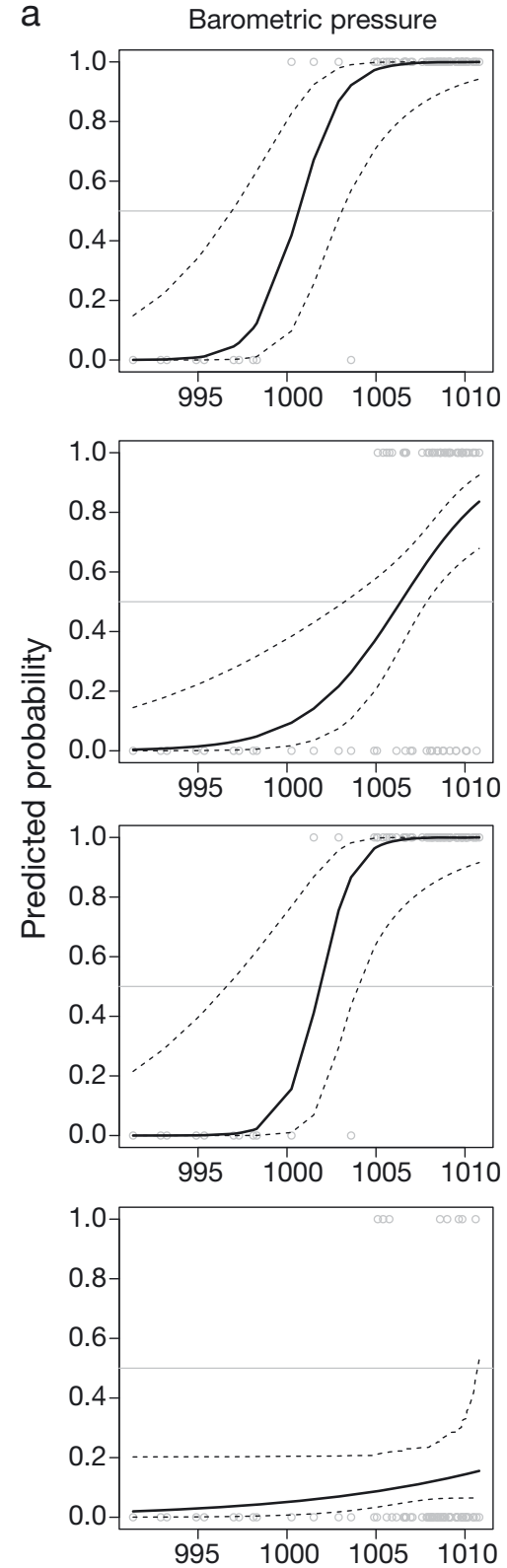

b

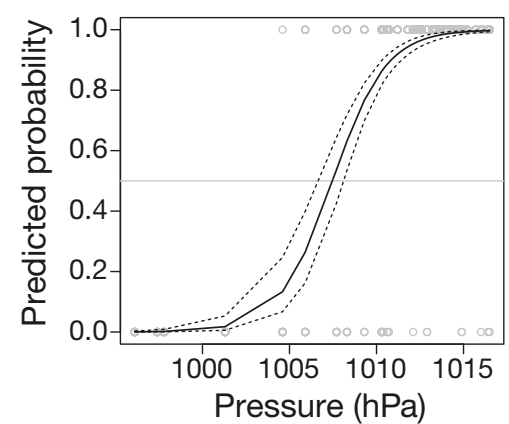

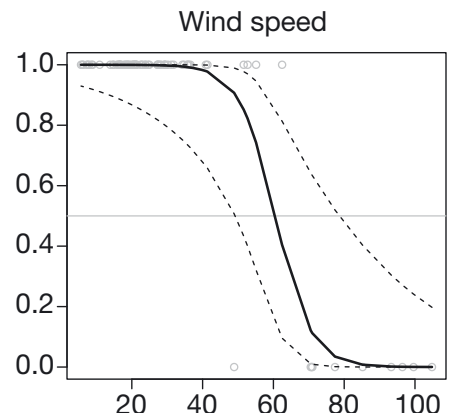
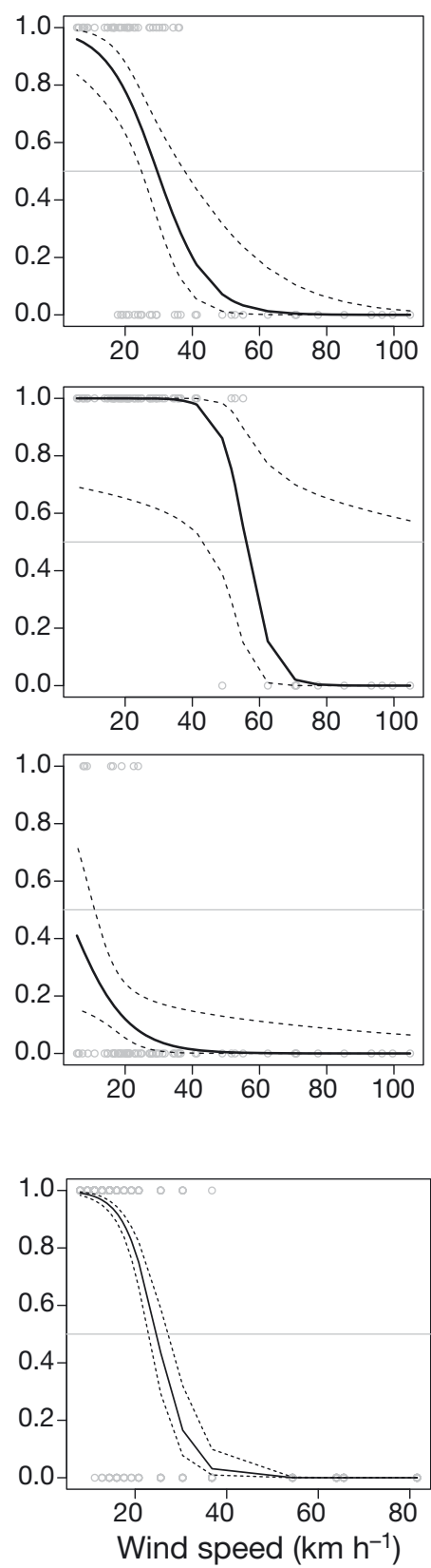
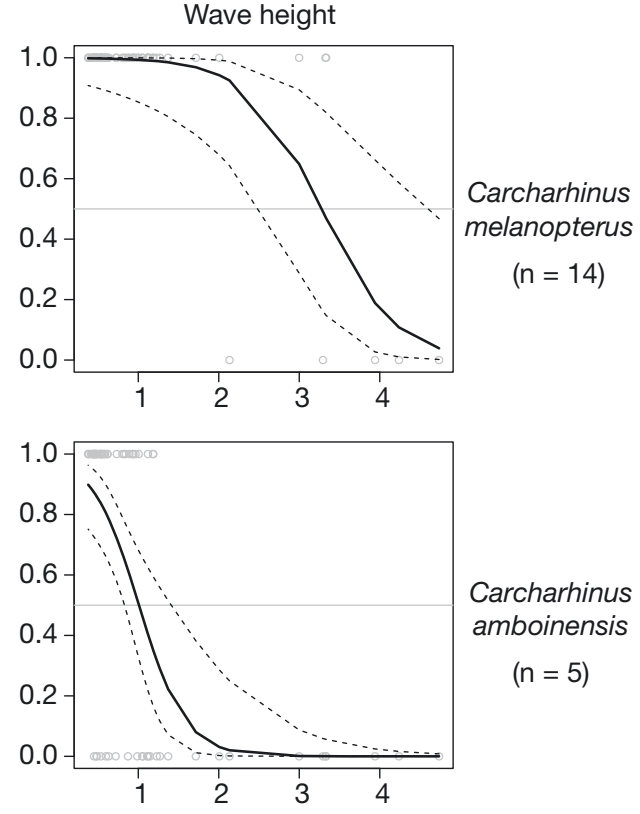

Carcharhinus amboinensis

$(n=5)$

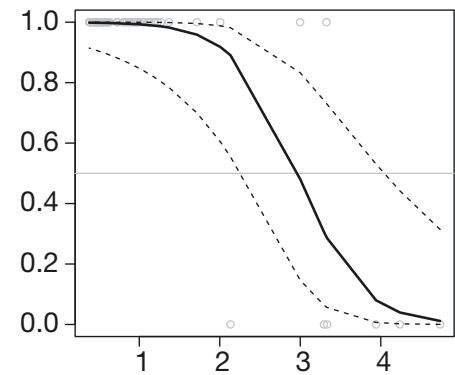

Carcharhinus sorrah

$(\mathrm{n}=8)$

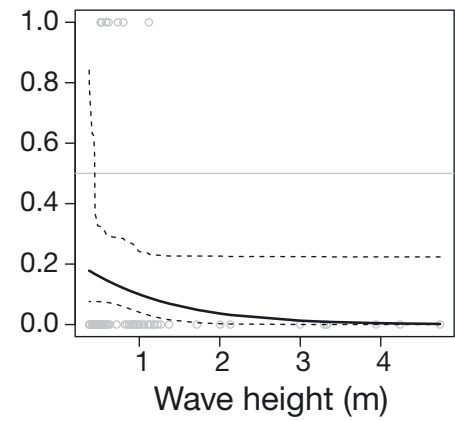

Carcharhinus tilstoni

$(\mathrm{n}=3)$
Carcharhinus limbatus

$(n=13)$

Fig. 5. Carcharhinus spp. Logistic regression analysis. Plots show the predicted probability of individuals present within the study sites. (a) Presence and absence within Cleveland Bay prior to Tropical Cyclone Yasi, with a fitted logit link function. Exit-entry detection data suggest that Carcharhinus melanopterus were present within the bay during the storm; therefore, these threshold values represent a function of receiver performance. C. tilstoni yielded unreliable values due to a function of low residency within the bay prior to the storm. (b) Presence and absence of C. limbatus within Terra Ceia Bay prior to Tropical 
Table 1. Carcharhinus spp. Environmental thresholds for flight behaviour estimated using $\mathrm{p}=0.5$ of logistic regressions of presence/absence data within Cleveland Bay, Queensland, Australia, prior to Tropical Cyclone (TC) Yasi and within Terra Ceia Bay, Florida, USA, prior to Tropical Storm Gabrielle. Values represent the level of the environmental factor at which $50 \%$ of individuals were no longer detected within the array. Values for Carcharhinus melanopterus are a function of receiver performance, since these individuals did not leave during TC Yasi. Insufficient residency of $C$. tilstoni resulted in unreliable threshold values

\begin{tabular}{|lcccc|}
\hline & $\mathrm{n}$ & $\begin{array}{c}\text { Barometric } \\
\text { pressure } \\
(\mathrm{hPa})\end{array}$ & $\begin{array}{c}\text { Wind } \\
\text { speed } \\
\left(\mathrm{km} \mathrm{h}^{-1}\right)\end{array}$ & $\begin{array}{c}\text { Wave } \\
\text { height } \\
(\mathrm{m})\end{array}$ \\
\hline $\begin{array}{l}\text { Cleveland Bay } \\
\text { Carcharhinus } \\
\text { melanopterus }\end{array}$ & 14 & 993.3 & 77.2 & 3.3 \\
$\begin{array}{l}\text { C. amboinensis } \\
\text { C. sorrah }\end{array}$ & 5 & 1006.4 & 29.5 & 1.0 \\
$\begin{array}{l}\text { C. tilstoni } \\
\text { Terra Ceia Bay }\end{array}$ & 8 & 1001.9 & 56.1 & 2.9 \\
C. limbatus & 13 & - & - & - \\
& 13 & 1007.4 & 24.6 & NA \\
\hline
\end{tabular}

activity space (mean proportion of overlap of $77 \%$ ) than core activity space (mean proportion of overlap of $61 \%$ ).

In contrast, there were significant differences in core activity spaces of Carcharhinus limbatus before and after TS Gabrielle in Terra Ceia Bay (Table 2). There was no significant effect of sex or length on core activity space. The extent of activity spaces was also significantly different before and after the storm, with both length and sex being non-significant covariates (Table 2). Overlap analysis showed a high degree of overlap between the extent of activity space of individuals before and after TS Gabrielle (mean proportion of overlap of $81 \%$; Fig. 6b). The proportion of overlap in core activity space was lower than the extent of activity space (mean proportion of overlap of $40 \%$ ).

\section{DISCUSSION}

The data presented in this study demonstrate that tropical storms can have significant short-term effects on the behaviour and movement of coastal sharks. The short-term responses displayed by most of the studied species, with the exception of Carcharhinus melanopterus, from 2 continents were consistent with individuals leaving their respective coastal bay environments prior to tropical storms making landfall. The synchronicity in the flight response of individuals in Cleveland Bay and Terra Ceia Bay suggests that sharks could detect and interpret the onset of acute changes in environmental conditions. This ability to detect subtle changes in conditions may allow individuals to predict approaching physical disturbances such as increased sedimentation, storm surges or large waves and leave before conditions worsen, therefore allowing them to avoid adverse conditions. Heupel et al. (2003) came to a similar conclusion when examining behavioural responses of $C$. limbatus in Terra Ceia

Table 2. Carcharhinus spp. Analysis of covariance for kernel utilisation distribution (KUD) estimates of activity space, where 50 and $95 \%$ KUD represent the core and the extent of the activity space, respectively, for all individuals in Cleveland Bay before and after Tropical Cyclone Yasi and in Terra Ceia Bay before and after Tropical Storm Gabrielle. Covariates: sex and stretch total length (STL); $\alpha=0.05$

\begin{tabular}{|c|c|c|c|c|c|c|c|c|c|c|c|c|}
\hline \multirow{2}{*}{ Taxon } & \multirow[t]{2}{*}{$\mathrm{n}$} & \multirow{2}{*}{ Covariate } & \multicolumn{5}{|c|}{$-50 \% \mathrm{KUD}$} & \multirow{2}{*}{$\begin{array}{c}\overline{\mathrm{x}}_{\mathrm{BEFORE}} \\
\left(\mathrm{km}^{2}\right)\end{array}$} & \multicolumn{2}{|c|}{$-95 \% \mathrm{KUI}$} & \multirow[b]{2}{*}{$F$} & \multirow[b]{2}{*}{$\mathrm{p}$} \\
\hline & & & $\begin{array}{c}\overline{\mathrm{x}}_{\mathrm{BEFORE}} \\
\left(\mathrm{km}^{2}\right)\end{array}$ & $\begin{array}{l}\overline{\mathrm{x}}_{\mathrm{AFTEP}} \\
\left(\mathrm{km}^{2}\right)\end{array}$ & $\mathrm{R} d f$ & $F$ & $\mathrm{p}$ & & $\begin{array}{l}\overline{\mathrm{x}}_{\text {AFTER }} \\
\left(\mathrm{km}^{2}\right)\end{array}$ & $\mathrm{df}$ & & \\
\hline Cleveland Bay & & & & & & & & & & & & \\
\hline Carcharhinus melanopterus & 12 & $\begin{array}{l}\text { Sex } \\
\text { STL }\end{array}$ & 4.44 & 4.27 & 1,11 & $\begin{array}{l}0.217 \\
0.157\end{array}$ & $\begin{array}{l}0.647 \\
0.696\end{array}$ & 24.81 & 23.43 & 1,11 & $\begin{array}{r}<0.001 \\
0.002\end{array}$ & $\begin{array}{l}0.988 \\
0.962\end{array}$ \\
\hline C. amboinensis & 8 & $\begin{array}{l}\text { Sex } \\
\text { STL }\end{array}$ & 6.84 & 8.49 & 1,7 & $\begin{array}{l}0.032 \\
0.054\end{array}$ & $\begin{array}{l}0.863 \\
0.822\end{array}$ & 40.44 & 54.00 & 1,7 & $\begin{array}{l}0.165 \\
0.055\end{array}$ & $\begin{array}{l}0.695 \\
0.820\end{array}$ \\
\hline C. sorrah & 6 & $\begin{array}{l}\text { Sex } \\
\text { STL }\end{array}$ & 8.68 & 6.30 & 1,5 & $\begin{array}{l}0.475 \\
0.032\end{array}$ & $\begin{array}{l}0.504 \\
0.860\end{array}$ & 41.09 & 36.25 & 1,5 & $\begin{array}{l}0.132 \\
0.284\end{array}$ & $\begin{array}{l}0.722 \\
0.604\end{array}$ \\
\hline C. tilstoni & 3 & $\begin{array}{l}\text { Sex } \\
\text { STL }\end{array}$ & 13.43 & 13.71 & 1,2 & $\begin{array}{l}4.047 \\
0.008\end{array}$ & $\begin{array}{l}0.182 \\
0.932\end{array}$ & 60.85 & 69.40 & 1,2 & $\begin{array}{l}0.492 \\
1.416\end{array}$ & $\begin{array}{l}0.556 \\
0.356\end{array}$ \\
\hline $\begin{array}{l}\text { Terra Ceia Bay } \\
\text { C. limbatus }\end{array}$ & 17 & $\begin{array}{l}\text { Sex } \\
\text { STL }\end{array}$ & 0.96 & 1.88 & 1,16 & $\begin{array}{l}2.36 \\
2.42\end{array}$ & $\begin{array}{l}0.144 \\
0.139\end{array}$ & 4.91 & 9.22 & 1,16 & $\begin{array}{l}3.18 \\
2.23\end{array}$ & $\begin{array}{l}0.093 \\
0.155\end{array}$ \\
\hline
\end{tabular}



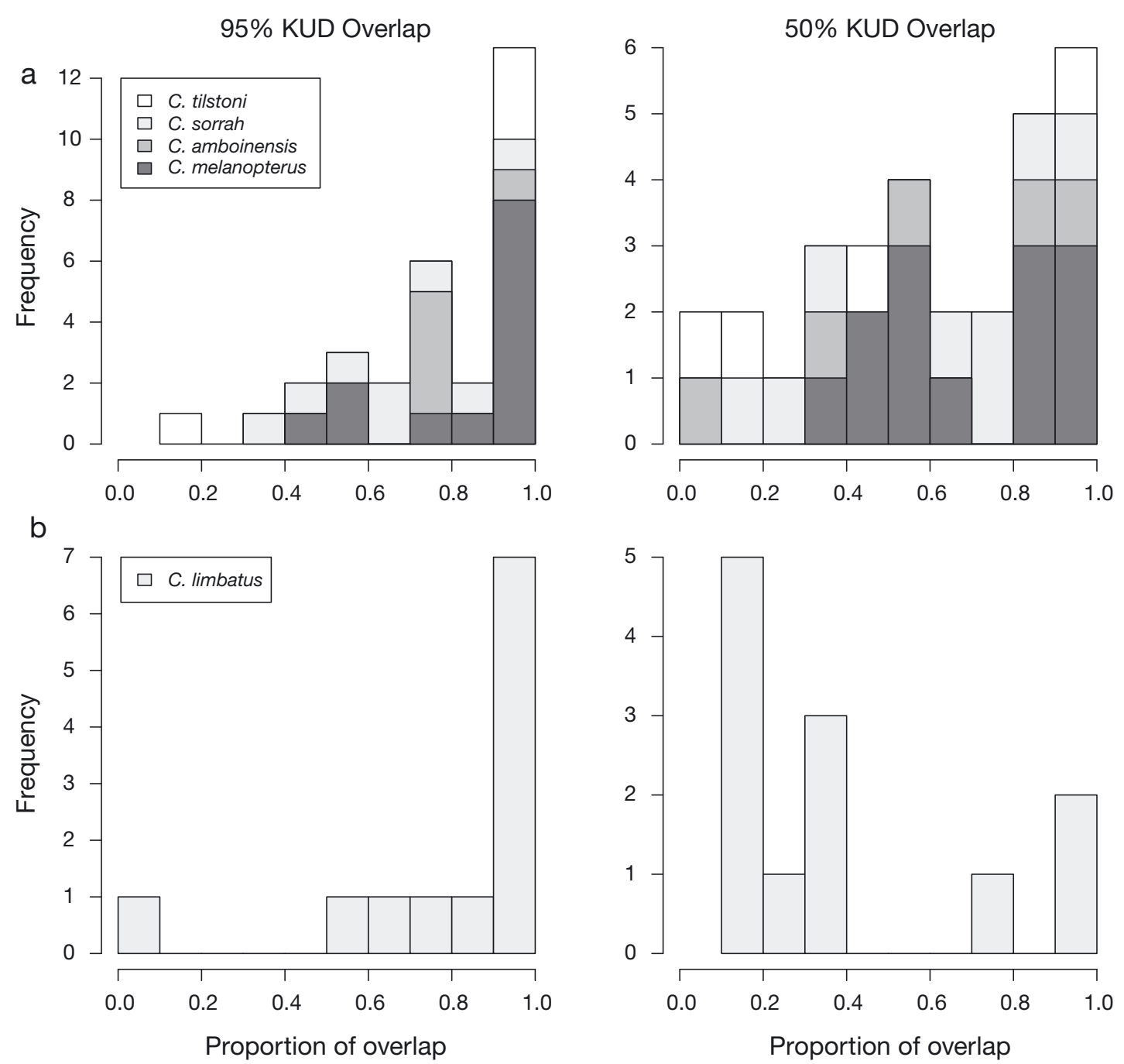

Fig. 6. Carcharhinus spp. Distribution of proportions of overlap of activity spaces (kernel utilisation distribution, KUD, where 50 and $95 \%$ KUD represent the core and the extent of the activity space, respectively) before and after (a) Tropical Cyclone Yasi in Cleveland Bay and (b) Tropical Storm Gabrielle in Terra Ceia Bay

Bay during TS Gabrielle and Hurricane Gordon. Similar flight responses have also been observed in Pristis pectinata (Simpfendorfer et al. 2005, Simpfendorfer \& Wiley 2006) and Negaprion brevirostris, C. leucas, C. limbatus and Sphyrna tiburo (M. Heupel unpubl. data), suggesting similar synchronous flight responses in a range of coastal shark species. Other marine animals including teleosts (Patterson et al. 2001), marine reptiles (Dodd \& Byles 2003, Liu et al. 2010) and invertebrates (Jury et al. 1995) also display flight responses to approaching storms, with individuals being encountered less frequently in shallow environments prior to large storm events. This suggests that animals may actively leave these environments to seek refuge in deeper water.
Many sharks are heavily dependent on coastal habitats that provide ecological functions such as nursery or foraging grounds (e.g. Castro 1993, Simpfendorfer \& Milward 1993, Knip et al. 2010). The use of these habitats may be affected by environmental conditions that could cause short- to longterm changes in the utility of these areas for coastal species. In extreme weather conditions, increased winds cause increased wave height, resuspend large amounts of sediment and increase current intensity (Thistle 1981, Posey et al. 1996, Davis et al. 2004). Logistic regression results suggested that different species have different tolerances to degrading conditions, which is also reflected in the short-term presence of these animals prior to storm events. 
Long-term monitoring of and habitat use by both Carcharhinus amboinensis and C. sorrah within Cleveland Bay have shown that $C$. amboinensis had a greater preference for shallower water $(<3.0 \mathrm{~m}$; Knip et al. 2011a), whereas C. sorrah had a greater affinity to deeper habitats (>4.0 m; Knip et al. 2012). Similarly, long-term studies and surveys within nursery bays in Florida have shown that C. limbatus are consistently found in shallow waters (e.g. Terra Ceia Bay: Heupel et al. 2004, Florida Bay: Wiley \& Simpfendorfer 2007), with fishing surveys catching $50 \%$ of individuals at depths between 1.8 and $3.0 \mathrm{~m}$ (Wiley \& Simpfendorfer 2007). These differences in depth use may explain some of the differences in flight responses in these species during the onset of storm events. C. amboinensis displayed the lowest threshold values to the approaching storm and left the bay before $C$. sorrah because the storm may have posed a greater threat in shallower waters. The depth at which these animals prefer to live may have an influence on their ability to perceive rapidly changing conditions or their need to move away prior to large disturbance events and thus may have an effect on their short-term responses.

Carcharhinus melanopterus displayed little discernible movement and remained within Cleveland Bay as TC Yasi approached. Similar non-flight behaviour was observed in this species at Orpheus Island $\left(18.63^{\circ} \mathrm{S}, 146.49^{\circ} \mathrm{E}\right.$; also within the storm's path) during TC Yasi (A. Schlaff unpubl. data). This species is known to have a high level of site fidelity (Papastamatiou et al. 2009, 2010) and their response to TC Yasi suggests that the benefits gained by individuals that remain in preferred habitats may outweigh the benefits of departing during adverse conditions, or that this species is more tolerant of the conditions experienced in shallow waters during storm events. The physical arrangement of the areas used by $C$. melanopterus within Cleveland bay (e.g. reef environments) may have also led to these sharks refraining from moving in response to TS Yasi. All individuals in this case occupied areas in the lee of Magnetic and Orpheus Islands, which may have provided some degree of shelter. However, further investigation is required to determine reasons for this non-flight response during unfavourable conditions.

Interestingly, presence and movement data within Cleveland Bay showed that individuals did not respond to TC Anthony in the same way they did to TC Yasi. Environmental conditions during TC Anthony did not reach the estimated barometric threshold values for all species within Cleveland Bay and may have been the reason for the lack of a flight response. Heupel et al. (2003) observed that Carcharhinus limbatus displayed weaker responses to Hurricane Gordon than to TS Gabrielle and suggested that the differences in the rate of decline in barometric pressure resulted in the different responses. This may indicate that the environmental variable that defines the threshold for a response may be the sudden change in conditions rather than an absolute threshold value; however, further study is required to test this hypothesis.

Similarity of activity space sizes before and after TC Yasi in Cleveland Bay suggests that the onset of storm events had little effect on how animals used space within the bay prior to leaving and on return. Within Terra Ceia Bay, however, increased activity space size before and after the storm showed that individuals used a larger area within the nursery after the disturbance event. This varying result between Cleveland Bay and Terra Ceia Bay may have been a function of the differences in the properties of the bays themselves and the proximity to the storms. Terra Ceia Bay is shallower and more restricted than Cleveland Bay, and therefore weather effects may have been more prominent and longer lasting than in Cleveland Bay. The closer proximity of TS Gabrielle to Terra Ceia Bay as compared to TCs Anthony and Yasi may have also been a confounding factor in the observed responses of animals using the respective areas. In addition, Carcharhinus limbatus in Terra Ceia Bay are known to migrate from this region in the autumn (September to November), so it is possible that sharks used more space as an ontogenetic shift or in preparation for migration (Heupel 2007).

Movement and space use data showed little differences in activity space size and location before and after TC Yasi, suggesting that individuals that returned after storm passage most likely used very different cues to return, and actively sought the habitats they utilised prior to storm events. This also suggests that they were able to navigate back to specific areas after severe disturbance events. Similar patterns were observed in Terra Ceia Bay, where individuals returned to their previous activity space locations after conditions stabilised. Some young sharks have been observed to have a homing ability, returning to a preferred habitat after being displaced (Edrén \& Gruber 2005). This may suggest that sharks use homing to navigate back to preferred habitats even after storm events have displaced them.

Another noteworthy result of this study was the observed synchronicity of the response of Carcharhi- 
nus tilstoni, C. sorrah and C. amboinensis, despite varying age classes and residency within Cleveland Bay prior to storm events. The majority of $C$. tilstoni tagged at the start of 2011 were juvenile and would not have experienced tropical storm conditions in their lifetime, suggesting that flight behaviour is an innate response. Heupel et al. (2012) examined movement metrics for C. limbatus in Terra Ceia Bay, and concluded that similarities in space use across naïve cohorts were indicative of innate behaviour. Innate response to tropical storms by naïve individuals was also observed by Heupel et al. (2003). The intraspecific differences observed in the responses of some species to the onset of disturbance events have greater implications for the conservation and management of coastal sharks in the face of habitat alterations and large disturbance events. This study showed that species with more plastic behaviours might be better adapted for a changing environment.

Large disturbance events have obvious, but shortterm, effects on the habitat use of many coastal shark species. The prompt return of sharks to specific locations demonstrates the importance of coastal habitats to their populations. With increased intensity of storms predicted by climate change models (Hobday \& Lough 2011), changes in the quality of habitats within coastal environments may have important implications for the long-term survival of elasmobranchs that use these areas. For example, if multiple severe storms occur in quick succession, populations may be displaced and unable to return for extended periods due to altered environmental conditions such as decreased salinity. The combination of extreme weather events and other factors such as coastal development, increased fishing pressure and habitat degradation and loss highlights the need for understanding the response of coastal elasmobranchs to changes in their environment (Chin et al. 2010).

Acknowledgements. We thank the staff and students of the Fishing and Fisheries Research Group, including F. de Faria, A. Schlaff, J. White, O. Li, P. Yates, S. Monroe and other volunteers who assisted with fieldwork related to this project. This research was funded by the Department of Employment, Economic Development and Innovation (DEEDI), under DEEDI's Marine Fish Habitat Scholarships Program, and additional funding was granted by AIMS@JCU and the School of Earth and Environmental Sciences, James Cook University. Environmental data within Cleveland Bay were sourced from the Australian Institute of Marine Sciences (AIMS) and the Department of Environmental and Resource Management (DERM), and data within Terra Ceia Bay were sourced from the Mote Marine Laboratory Weather Station, Florida.

\section{LITERATURE CITED}

Calenge C (2006) The package 'adehabitat' for the R software: a tool for the analysis of space and habitat use by animals. Ecol Model 197:516-519

Calenge C (2011) Home range estimation in R: the adehabitatHR package. The Comprehensive R Archive Network http://cran.r-project.org/web/packages/adehabitatHR/ vignettes/adehabitatHR.pdf

$>$ Castro JI (1993) The shark nursery of Bulls Bay, South Carolina, with a review of the shark nurseries of the southeastern coast of the United States. Environ Biol Fishes 38: $37-48$

- Chin A, Kyne PM, Walker TI, McAuley RB (2010) An integrated risk assessment for climate change: analysing the vulnerability of sharks and rays on Australia's Great Barrier Reef. Glob Change Biol 16:1936-1953

> Davis SE III, Cable JE, Childers DL, Coronado-Molina C and others (2004) Importance of storm events in controlling ecosystem structure and function in a Florida Gulf coast estuary. J Coast Res 20:1198-1208

Dodd KC Jr, Byles R (2003) Post-nesting movements and behaviour of loggerhead sea turtles (Caretta caretta) departing from east-central Florida nesting beaches. Chelonian Conserv Biol 4:1-7

Edrén SMC, Gruber SH (2005) Homing ability of young lemon sharks, Negaprion brevirostris. Environ Biol Fishes 72:267-281

Fraser PJ, Shelmerdine RL (2002) Dogfish hair cells sense hydrostatic pressure. Nature 415:495-496

Heupel MR (2007) Exiting Terra Ceia Bay: an examination of cues stimulating migration from a summer nursery area. Am Fish Soc Symp 50:265-280

Heupel MR, Hueter RE (2001) Use of an automated acoustic telemetry system to passively track juvenile blacktip shark movements. In: Sibert JR, Nielsen JL (eds) Electronic tagging and tracking in marine fisheries. Kluwer Academic Publishers, Dordrecht, p 217-236

Heupel MR, Simpfendorfer CA, Hueter RE (2003) Running before the storm: Blacktip sharks respond to falling barometric pressure associated with tropical storm Gabrielle. J Fish Biol 63:1357-1363

> Heupel MR, Simpfendorfer CA, Hueter RE (2004) Estimation of shark home ranges using passive monitoring techniques. Environ Biol Fishes 71:135-142

> Heupel MR, Simpfendorfer CA, Olsen EM, Moland E (2012) Consistent movement traits indicative of innate behavior in neonate sharks. J Exp Mar Biol Ecol 432-433:131-137

Hobday AJ, Lough JM (2011) Projected climate change in Australian marine and freshwater environments. Mar Freshw Res 62:1000-1014

Jury SH, Howell WH, Watson WH III (1995) Lobster movements in response to a hurricane. Mar Ecol Prog Ser 119: 305-310

> Knip DM, Heupel MR, Simpfendorfer CA (2010) Sharks in nearshore environments: models, importance, and consequences. Mar Ecol Prog Ser 402:1-11

Knip DM, Heupel MR, Simpfendorfer CA, Tobin AJ, Moloney $\mathrm{J}$ (2011a) Ontogenetic shifts in movement and habitat use of juvenile pigeye sharks Carcharhinus amboinensis in a tropical nearshore region. Mar Ecol Prog Ser 425:233-246

Knip DM, Heupel MR, Simpfendorfer CA, Tobin AJ, Moloney J (2011b) Wet-season effects on the distribution of juvenile pigeye sharks, Carcharhinus amboinensis, in tropical nearshore waters. Mar Freshw Res 62:658-667 
Knip DM, Heupel MR, Simpfendorfer CA (2012) Habitat use and spatial segregation of adult spottail sharks, Carcharhinus sorrah, in tropical nearshore waters. J Fish Biol 80:767-784

Liu YL, Lillywhite HB, Tu MC (2010) Sea snakes anticipate tropical cyclone. Mar Biol 157:2369-2373

Matich P, Heithaus MR (2012) Effects of an extreme temperature event on the behavior and age structure of an estuarine top predator, Carcharhinus leucas. Mar Ecol Prog Ser 447:165-178

Papastamatiou YP, Lowe CG, Caselle JE, Friedlander AM (2009) Scale-dependent effects of habitat on movements and path structure of reef sharks at a predator-dominated atoll. Ecology 90:996-1008

Papastamatiou YP, Friedlander AM, Caselle JE, Lowe CG (2010) Long-term movement patterns and trophic ecology of blacktip reef sharks (Carcharhinus melanopterus) at Palmyra atoll. J Exp Mar Biol Ecol 386:94-102

Patterson WF, Watterson JC, Shipp RL, Cowam JH Jr (2001) Movement of tagged red snapper in the northern Gulf of Mexico. Trans Am Fish Soc 130:533-545

Posey M, Lindberg W, Alphin T, Vose F (1996) Influence of storm disturbance on an offshore benthic community. Bull Mar Sci 59:523-529

Simpfendorfer CA, Milward NE (1993) Utilization of a tropical bay as a nursery area by sharks of the families Carcharhinidae and Sphyrnidae. Environ Biol Fishes 37: $337-345$

Editorial responsibility: Janet Ley, St. Petersburg, Florida, USA
Simpfendorfer CA, Wiley TR (2006) Impact of Hurricane Charley on the movements and habitat use of juvenile smalltooth sawfish. Tech Rep 1133. Center for Shark Research, Mote Marine Laboratory, Sarasota, FL

Simpfendorfer CA, Heupel MR, Hueter RE (2002) Estimation of short-term centers of activity from an array of omnidirectional hydrophones and its use in studying animal movements. Can J Fish Aquat Sci 59:23-32

Simpfendorfer CA, Wiley TR, Yeiser BG (2005) Effect of Hurricane Charley on smalltooth sawfish (Pristis pectinata) nursery habitats in Charlotte Harbor, Florida. Tech Rep 1046. Center for Shark Research, Mote Marine Laboratory, Sarasota, FL

Simpfendorfer CA, Heupel MR, White WT, Dulvy NK (2011) The importance of research and public opinion to conservation management of sharks and rays: a synthesis. Mar Freshw Res 62:518-527

> Thistle D (1981) Natural physical disturbances and communities of marine soft bottoms. Mar Ecol Prog Ser 6: $223-228$

> Ubeda AJ, Simpfendorfer CA, Heupel MR (2009) Movements of bonnetheads, Sphyrna tiburo, as a response to salinity change in a Florida estuary. Environ Biol Fishes 84:293-303

Wiley TR, Simpfendorfer CA (2007) The ecology of elasmobranchs occurring in the Everglades National Park, Florida: implications for conservation and management. Bull Mar Sci 80:171-189

Submitted: September 18, 2012; Accepted: December 29, 2012 Proofs received from author(s): April 8, 2013 